\title{
The Optimal and Sustainable Model of Land Use Facing Sea Water Intrusion through Partnership Patterns (Case Study Untia Village, Makassar City)
}

\author{
Meyke Nadjamuddin Sultan ${ }^{1}$, Soemarno $^{2}$, Harsuko Riniwati ${ }^{3}$, Andi Tamsil ${ }^{4}$ \\ \{sultanmeyke@gmail.com ${ }^{1}$, smno@ub.ac.id ${ }^{2}$, riniwatisepk@gmail.com ${ }^{3}$, andi.tamsil@umi.ac.id ${ }^{4}$ \} \\ Universitas Brawijaya, Indonesia ${ }^{1,2,3}$ \\ Universitas Muslim Indonesia, Indonesia ${ }^{4}$
}

\begin{abstract}
High population growth along with economic growth led to the conversion of productive land into residential and industrial areas. High pressure on the land can have an impact on groundwater conditions. For this reason, the study of optimal and sustainable land use models facing sea water intrusion through partnership patterns is very important. The type of data used in the study of optimal and sustainable land use models facing sea water intrusion through partnership patterns is the primary data type. Data collection methods used models facing sea water intrusion through partnership patterns are survey methods. The data analysis method used in the study of optimal and sustainable land use models facing sea water intrusion through partnership patterns is the AHP (Analytic Hierarchy Process) method. The analysis results are obtained; 1) The type of land use for offices is a top priority related to the criteria for optimal and sustainable land use models with a coefficient value of 0.3302 or around $33.03 \%$. 2) Ground water as a source of clean water is the main priority for the use of ground water in the study location, with a coefficient of 0.4355 or around $43.55 \%$. 3) Community based protection model for vulnerable/vulnerable areas (sea water intrusion) and increased adaptation are the main priorities with a coefficient of 0.4783 or around $47.83 \%$.
\end{abstract}

Keywords: Sustainable, Land Use, Sea Water, Intrusion, Makassar City.

\section{Introduction}

The optimalization and sustainable land use model are the current development demand, especially in the development of areas related to natural resource use, especially in coastal areas that are vulnerable/prone to disasters, such as sea water intrusion. Land use is closely related to the urban form, it seems like the study location is in the coastal area of Makassar City. According to Bourne [1] that urban form is a spatial pattern or arrangement of every element in an urban area, both buildings and land uses (collectively forming a built environment) including the order of social groups, economic activities and public institutions. It can also be interpreted as a spatial combination of individual elements to build/shape the environment as social groups, economic activities and public institutions.

Various forms of land use that are generally found in urban areas, including; offices, settlements, public facilities, shops, and productive land. But in some big cities, productive land is rarely found. High population growth along with economic growth led to the conversion of productive land into residential and industrial areas. It because the need for shelter is a major 
need in urban areas. To find out the optimalization and sustainable land use model, AHP analysis was performed. The model developed is a model with a partnership pattern. The partnership pattern is defined as a form of mutually beneficial cooperation between two or more parties to achieve a common goal. The impact of salt water intrusion can be minimized, various models of approaches can be carried out, including the partnership pattern. Thus, the study of optimalization and sustainable land use models facing sea water intrusion through partnership patterns is very important.

\section{Material and Method}

\subsection{Data Types and Sources}

This research used primary data Primary data in this study were obtained from expert respondents who were the results of expert judgments. The number of expert respondents was 6 people who were considered to understand groundwater management in Makassar City. The number of expert respondents is considered to be sufficiently representative as Hora [2] stated that the number of experts who are adequate and have high precision is as much as 3 to 6 or 7 persons.

\subsection{Data Collecting Method}

Data collection method was a survey (questionnaire). The questionnaire was intended to obtain answers or expert opinion (expert judgment) related to the optimal and sustainable land use model facing sea water instruction with a partnership pattern. According to Arikunto [3] that the questionnaire is a data collection technique by submitting or sending a list of questions to be filled in by respondents.

\subsection{Data Analysis Method}

The AHP (Analytic Hierarchy Process) method was used for data analysis. This method aimed to determine decisions developed by Saaty by 1970s. AHP method can be used to measure the importance of qualitative matters with a high level of complexity [4]. The reason for using AHP is because in the AHP there is the concept of eigenvector which is used to process the priority ranking of each criterion based on a pairwise comparison matrix [5].

The AHP steps are by Suryadi and Ramdani [6] a) Define the problem and determine the desired solution, b) Create a hierarchical structure that starts with the main goal (goals), c) Make a pairwise comparison matrix that describes the relative contribution or influence of each element on the goal or criteria level above, d) Define the comparison in pairs so that the total rating is obtained as many as $\mathrm{nx}[(\mathrm{n}-1) / 2]$ pieces, where $\mathrm{n}$ is the number of elements compared, e) Calculate eigenvalues and test their consistency, f) Repeat steps 3,4, and 5 for all levels of the hierarchy, g) Calculates the eigenvectors of each paired comparison matrix, and h) Checks the consistency of the hierarchy.

Table 1. The intensity scale of importance on the pairwise comparison matrix

Intensity of importance Description




\begin{tabular}{cl}
\hline 1 & Both criteria are equally important \\
3 & One criterion is slightly more important than the other criteria \\
5 & One criterion is more important than the other criteria \\
9 & One criterion is clearly more important than the other criteria \\
$2,4,6,8$ & $\begin{array}{l}\text { One criterion is absolutely more important than the other criteria } \\
\text { Values between two criteria are considered close together } \\
\text { The opposite }\end{array}$ \\
& $\begin{array}{l}\text { If activity } i \text { gets one number compared to activity } j, \text { then } j \text { has the } \\
\text { inverse value of } i .\end{array}$
\end{tabular}

Source: Saaty [7].

\section{Results and Discussion}

Various forms/models of land use can be carried out, ranging from adaptation, mitigation to conservation models. According to Aldrian et al. [8] explained that the forms of response by the community to climate change or the disasters they faced could be divided into two, namely adaptation and mitigation. Marfai and Hizbaron [9] explain that community response to disasters is an important thing to learn in disaster risk management.

Mitigation is generally defined as an effort made to reduce and/or eliminate losses and casualties that may occur due to disasters, namely by making preparations before a disaster occurs. Furthermore, it is stated in Law Number 24 of 2007 on Disaster Management that mitigation is a series of efforts to reduce disaster risk, both through physical development and awareness raising and capacity to face the threat of disaster. While adaptation is interpreted as a way how the organism overcomes the pressure of the surrounding environment to survive. According to Aldrian et al. [8] that mitigation measures are more about efforts to reduce these impacts.

Disaster adaptation is an effort to adjust to the environment by making changes that lead to increased resilience and resilience to changes, such as adaptation to the availability of ground water by injecting water through infiltration wells and others. According to Aldrian et al. [8] adaptation actions related to the efforts made by the community to reduce the negative impacts arising from a natural phenomenon, such as; climate change or natural disasters and take advantage of these conditions. In this case adaptation is more likely to attempt to manage something that cannot be avoided.

Conservation is interpreted as an effort made so that the resources needed for life can still be able to serve the needs of human life, not damaged or quickly used up, Prawiro [10] if ground water as a resource experiences quality damage and decreases in quantity, then groundwater conservation efforts must be made. As a first step, groundwater conservation efforts are to monitor the quantity of ground water. Then the monitoring results are used as evaluation material in determining the next step in groundwater conservation.

Based on the theory and research results related to vulnerability to disasters, as has been developed during [8][11][12][13][14][15][16][9][17][18][19][20][8][21] then formulated 3 optimal and sustainable land use models in facing the vulnerability of sea water intrusion through partnership patterns, namely; 1) Models for protecting community-based vulnerable areas and enhancing environmental adaptation, 2) Models for determining disaster-prone areas and enhancing environmental mitigation, and 3) Partnership models for ecosystem conservation and establishing protected/strategic areas. Following are the results of the analysis of the priority of optimal and sustainable land use models. 


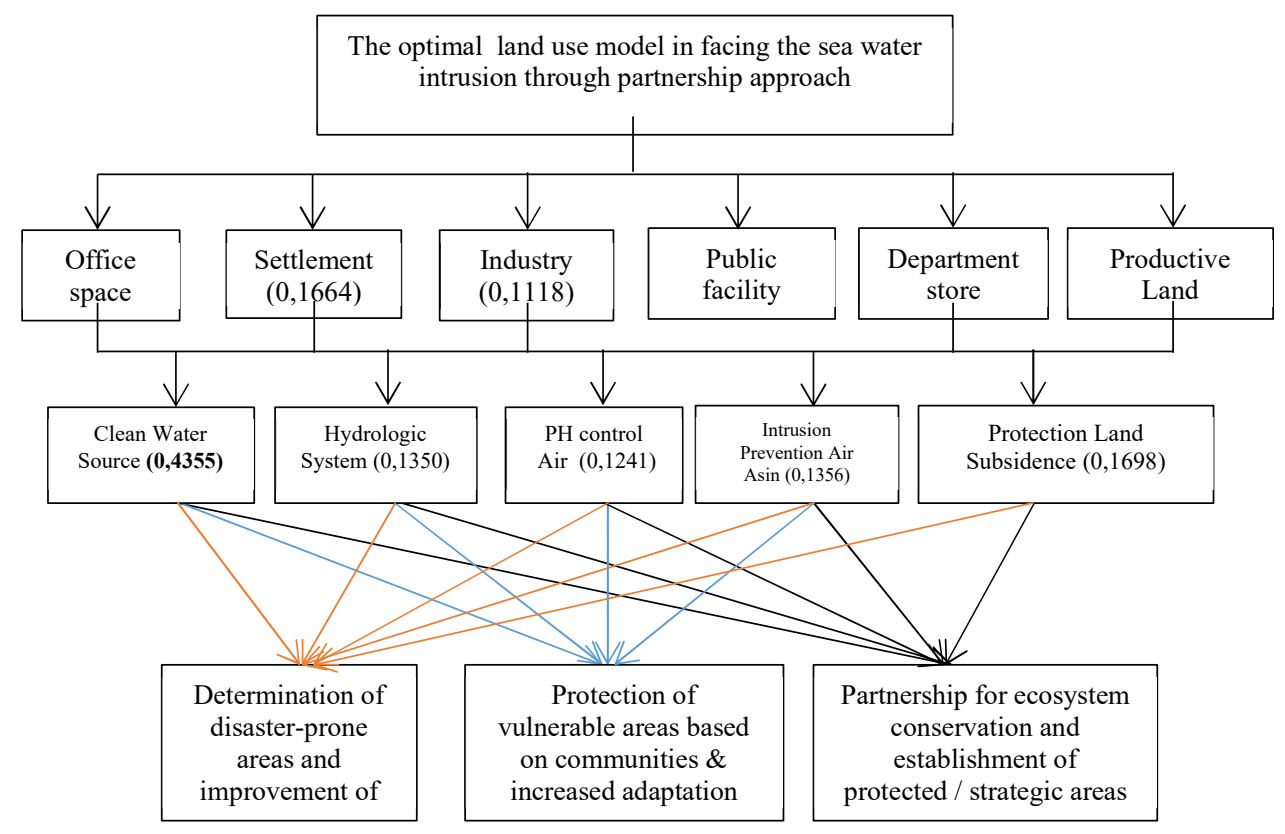

Fig. 1. Prioritization of the hierarchy/level of land use models that are optimal and sustainable.
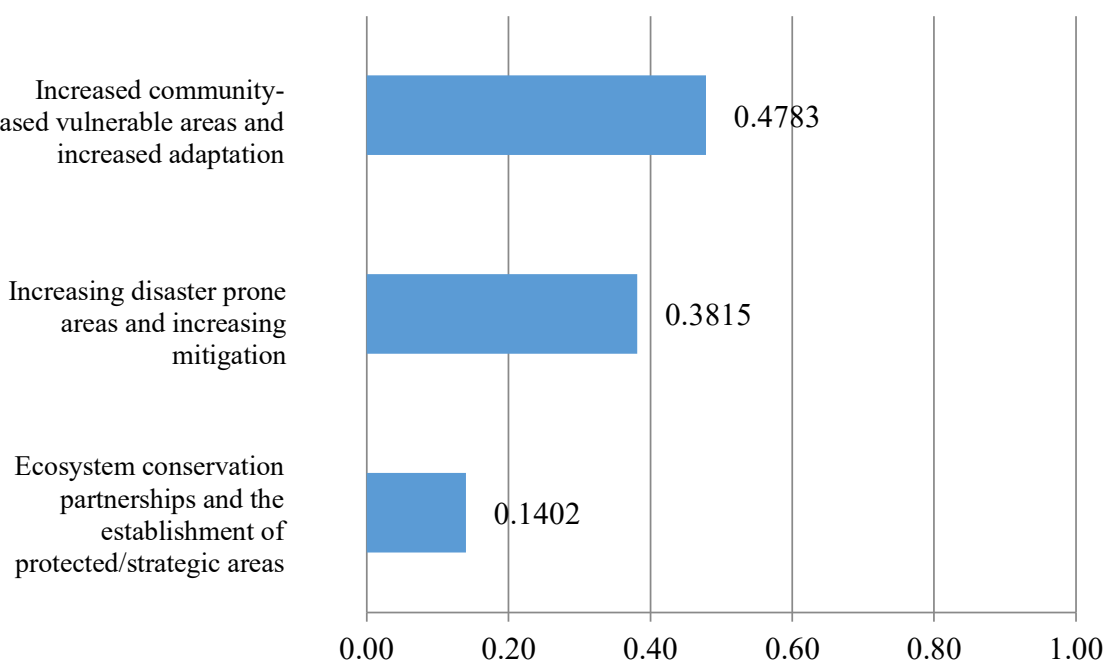

Fig. 2. Priority alternative models

Based on spatial mapping data (spatial) to the level of vulnerability of sea water intrusion (salt) it is known that an area of $1295.53 \mathrm{Ha}$ or around $80.79 \%$ of the area is categorized as vulnerable and very vulnerable. This condition illustrates that overall the study area is classified as vulnerable to sea water intrusion. The vulnerability of the region needs to be addressed with 
a variety of approaches including mitigation, adaptation and conservation measures with the partnership approach.

The results of the analysis of the priority of optimalization and sustainable land models for salt water intrusion through a partnership pattern obtained the first priority is a communitybased vulnerable area protection model and increased environmental adaptation (0.4783). The second priority is the model of establishing disaster prone areas and enhancing environmental mitigation (0.3815), and the third priority is the partnership model for ecosystem conservation and the establishment of protected/strategic areas $(0.1402)$.

\subsection{A model for protecting community-based vulnerable areas and increasing environmental adaptation.}

Some forms of protection of vulnerable/vulnerable seawater intrusion areas are carrying out protected area protection activities, such as; protection of mangrove areas, and green open spaces. Protection of mangrove areas can be done in a participatory manner or with a partnership pattern, where the community as the main base of the mangrove protection model is carried out. For example, of a partnership pattern for mangrove rehabilitation carried out between the government (KLHK) and the people of Takalar Village, Mappakasunggu District, Takalar, South Sulawesi. KLHK provides assistance of 25,000 seedlings for each farmer group or community in a year. Distribution of seeds, must be done in rotation for different farmer groups. In addition, several protection activities are carried out, including; building breakwaters, and installing embankments in coastal areas. It aimed to ensure mangroves or other coastal plants can grow well, so as to maintain good ground water circulation, where one of the functions of mangrove ecosystems is to prevent sea water intrusion, erosion and coastal abrasion [22]. Arief, [23] further stated that the function of mangrove forests is to settle mud at its roots, so as to prevent the occurrence of sea water intrusion to land.

In addition, adaptation measures are also taken as one form of community response to disasters/hazards that occur. According to Thomalla et al. and Twigg [24], that the response of local communities and community resilience to hazards and natural disasters are important subjects in disaster management studies. Community resilience is defined as an evaluation of people's competence to adapt and or to improve the current situation. A series of studies to identify coastal hazards, tidal flood management and the impact of land subsidence in coastal areas have been carried out [21]. Since the 2000s, it was revealed that the most common local adaptation carried out by local communities was in the form of structural or physical adaptation [25].

Adaptation measures to disasters/seawater intrusion hazards at the study site can be done based on the type of land use. Adaptation actions or strategies are the efforts or actions of the community to get used to or adapt themselves to the disasters they face, in this case the danger of seawater intrusion. According to Aldrian et al. [8], that in general the concept of adaptation strategies to disasters or vulnerabilities they face, includes; protection, accommodation and retreat.

Protection measures are protective measures undertaken by people affected by disasters to adjust to the impacts caused. In this case is protection against the effects of sea water intrusion. Protection measures with a partnership that can be done are the use of other water sources through rainwater harvesting. Development of media/rainwater harvesting ponds can be done with a partnership pattern between the government and the community or tripartite (government-private-community). Land for rainwater collection areas can be provided by the community, besides that the roofs of houses / residents' buildings are the source of the rainwater 
collection system which is then channeled to the reservoirs. While the cost of building a reservoir can be sourced from the government or the private sector or both. The purpose of making rainwater harvesting/harvesting is to overcome the limitations of clean water, as a result of sea water intrusion. Rainwater from the reservoir can then be channeled and used together by the community, government and the private sector. One example of the results of research by Nurnawaty [26] found that one form of seawater intrusion treatment is the use of cement soil bulkhead as a subsurface barrier which can reduce the length of saltwater intrusion. The longer the depth and thickness of the screen the intrusion length decreases. While one example of a partnership pattern related to rainwater harvesting is that developed by Coca-Cola Foundation Indonesia (CCFI) in 2018, which has developed the Green Rusunawa concept, which is a water management model through the use of rainwater in the form of a Rain Water Harvesting (RWH) system. The RWH model was developed in 3 Rusunawa Muara Baru blocks, North Jakarta.

In addition, efforts to overcome them also take the form of accommodation measures. The accommodation act is an adjustment effort made by the community to the impact caused by the environment. Marfai and Hizbaron's research [9] revealed that the people in Semarang were aware of the disasters/flood hazards that occurred, but this understanding did not support their decision to leave their region, and even the community had adapted to tidal flooding with adaptation strategies simple physical, like; raise the floor of the house/building to the water level and make a small dam to block water from entering the house. Although the response is aesthetically not quite beautiful from an environmental perspective, it is felt to be very helpful to the community from the danger of tidal floods.

Desalinization is a process that removes excess salt levels in water to get clean, edible water. Desalination is a separation process used to reduce the content of dissolved salt from salt water to a certain level so that water can be used. Desalination process products are generally water with a dissolved salt content of less than $500 \mathrm{mg} / 1$, which can be used for domestic, industrial and agricultural purposes. The by-product of the desalination process is brine. Brine is a high concentration salt solution (>35000 mg / 1). In general, there are two methods that are most widely used in seawater desalination (salty) namely; reverse osmosis method (47.2\%) and multi stage flash method $(36.5 \%)$. However, the costs required for the desalination method are quite large (expensive), so this method requires funding from the government or the private sector. In order to reduce costs, the tripatrit (public-private-community) partnership pattern is the best option that can be made, besides developing a small-scale desalination system with a reverse osmosis system. One small-scale desalination model that has been developed is the Sea Water Reverse Osmosis (SWRO) small capacity (150-1000 $\mathrm{m}^{3} /$ day) $40 \%$ recovery developed in Bali [27].

Other adaptation actions are retreat actions. The retreat action is the act of leaving the affected area by moving to a safer area [11]. The retreat strategy aims to avoid sea water intrusion by relocating, offices, settlements, industries, agricultural areas, and others towards land far from the sea. Thus, the area is not reached by sea water as a result of sea salt intrusion (salty). But retreat actions are relatively difficult to occur considering these actions require relatively large amounts of energy. The results of Marfai and Hizbaron's [9] research related to the tidal flood (rob) in Semarang City, revealed that community perceptions related to retreat actions were obtained instead of considering tidal floods (rob) as a risk, even the people in the study area tended to ignore the dangers and assume that Tidal flooding is no longer a threat to their safety, so they still choose to live in that location.

3.2 Model for determining disaster prone areas and increasing environmental mitigation 
The model for determining disaster-prone areas is conducted by referring to the results of the analysis of the spatial distribution of sea water (salt) intrusion and the level of vulnerability of the region based on the SVI (Szlafstein Vurnerability Index) method. The determination of seawater intrusion-prone areas/regions becomes very important, considering the level of intrusion that occurs is relatively high, on the other hand, the affected areas are also quite broad $(80.79 \%)$. The act of determining disaster-prone areas is carried out by the City Government, to be further socialized to the public and private sector and other stakeholders to carry out various mitigation efforts.

The model for determining disaster-prone areas is conducted by referring to the results of the analysis of the spatial distribution of sea water (salt) intrusion and the level of vulnerability of the region based on the SVI (Szlafstein Vurnerability Index) method. The determination of seawater intrusion-prone areas/regions becomes very important, considering the level of intrusion that occurs is relatively high, on the other hand, the affected areas are also quite broad $(80.79 \%)$. The act of determining disaster-prone areas is carried out by the City Government, to be further socialized to the public and private sector and other stakeholders to carry out various mitigation efforts.

Mitigation actions against seawater intrusion can be carried out with a partnership pattern between the government and the community or with the private sector or the three together (tripartite). Mitigation measures can be in the form of physical (structural) mitigation and nonphysical (non-structural) mitigation. Some mitigation actions against the danger of sea water intrusion, are; a) Making artificial brackish water supplies and in coastal areas to increase water supply into the transition zone, b) Making barriers or barriers in coastal areas for remediation and mitigation of intrusions, especially in shallow ground water, c) Carry out appropriate and continuous monitoring good for groundwater quality in areas categorized as critical and surrounding areas, d) expanding green open areas (RTH), e) expanding protected areas / areas, f) making artificial recharge through injection wells in areas categorized as critical and surrounding areas, f) Improve water management, including irrigation systems and networks, and $\mathrm{g}$ ) Perform spatial planning (non-structural mitigation).

\subsection{The partnership model for ecosystem conservation and the determination of protected/strategic areas}

Conservation is a protection and preservation effort. The ecosystem conservation partnership model is carried out through the conservation of land, water and protective plants. Land conservation is carried out by optimizing land management, including; a) Developing land and plant management technologies to improve the adaptability of plants, and b) rejuvenate the soil and plants, improve habitat. While groundwater conservation measures are carried out to maintain the availability (quality and quantity) of ground water, including; a) Does not recommend making/adding drill wells in areas categorized as critical and surrounding areas, b) Applying water-saving technology (water use efficiency), c) Increasing infiltration wells (biopori), d) Re-evaluating retrieval discharge to existing production bore wells in areas categorized as critical and surrounding areas, and e) Evaluating distances between wells in areas categorized as critical and surrounding areas. Whereas the plant/plant conservation measures undertaken include; a) Conducting beach vegetation planting such as mangroves, sea cucumbers, fir, etc., b) Restoring beach nourishment and mangrove rehabilitation.

Plant and land conservation actions are indirect effort to prevent sea water intrusion from occurring gradually. This relates to the purpose of conservation, which is to preserve natural resources while still being able to obtain benefits. In addition, protecting areas is very important 
to mitigate and adapt to salt water intrusion. Conservation actions of protective plants/plants such as mangroves will be carried out well if the protected area is first established. Likewise, with land conservation, it can be done well if a strategic area has been determined.

\section{Conclusion}

The results of the analysis and discussion obtained several conclusions as follows:

a) Settlement and industry are components of social systems that have a very high relationship with the integrity of the ecological system with a total value of 21 or an average of 3.50 .

b) The type of land use for offices is a top priority related to the criteria for optimal and sustainable land use models with a coefficient value of 0.3302 or around $33.03 \%$.

c) Groundwater as a source of clean water is the main priority for the use of ground water in the study location, with a coefficient of 0.4355 or around $43.55 \%$.

d) Community based protection model for vulnerable/vulnerable areas (sea water intrusion) and adaptation improvement are the main priorities with a coefficient of 0.4783 or around $47.83 \%$.

\subsection{Acknowledgements}

Special thanks to local government Makassar City.

\section{References}

[1] Bourne, L. S. Urban spatial structure: an introductory essay on concepts and criteria. In L. S. Bourne (Ed.), Internal structure of the city. Student Library, 1982.

[2] Hora, S.C. Probability judgments for continuous quantities: linear combinations and calibrations, Management Science, 50. 597-604, 2004.

[3] Arikunto, S. Research Procedure A practical approach. PT Rineka Cipta. Jakarta, 2010.

[4] Yulianti, E. and Juwita, F. Decision Support System for Culinary Site Selection Support in Padang City Using the Exponential Comparison Method (MPE). Journal of TEKNOIF, Vol.4 No. 2, 2016.

[5] Marimin. Concept and Application of Decision Support Systems. Yogyakarta: Andi Publisher, 2007.

[6] Suryadi, Kadarsah and Ali Ramdhani. Decision Support Systems: A Structural Discourse on Idealization and Implementation of Decision-Making Concept. Bandung: PT. Teen Rosdakarya, 2002.

[7] Saaty, T.L. Decision Making with the Analytical Hierarchy Process. Int. J. Services Sciences. Vol. 1. No. 1.p135-142, 2008.

[8] Aldrian E, Karmini M, and Budiman. Climate Change Adaptation and Mitigation in Indonesia. Jakarta: BMKG, 2011.

[9] Marfai M.A, and Hizbaron D.R. Community Adaptive Capacity Due to Coastal Flooding in Semarang Coastal City, Indonesia. Analele UniversităNíii din Oradea Seria Geografie, Year XXI, No. 2/2011 (December), p.209-221, 2011. 
[10] Prawiro, Ruslan. H. Environmental Ecology of Pollution. Satyawacana. Semarang, 1988.

[11] Dahuri, R. Adaptation Strategies for the Marine and Fisheries Sector in Facing Global Climate Change. LIPI: Jakarta, 2012.

[12] Adrian, D. Werner, Mark Bakker, Vincent E.A. Post, A. Vandenbohede, C. Lu; B. Ataie-Ashtiani, C.T. Simmons, and D.A. Barry. Seawater Intrusion Processes, Investigation and Management: Recent advances and future challenges. Advances in Water Resources, 51: 3-26, 2013. www.elsevier.com/locate/ advwatres.

[13] Hidir, T. Mitigation of Seawater Intrusion on the Coastal Coast in the Cilegon Industrial Zone. Proceedings of the ISOI XI Annual National Scientific Meeting. Balikpapan, 2014.

[14] Abarca, E. Seawater intrusion in complex geological environments. PhD thesis. TUC, Barcelona, Spain, 2006.

[15] Bambang, H. Intrusion in the Coastal District of Rembang, Central Java. Journal Of Geography. Geography and Teaching. ISSN 1412- 6982. e-ISSN: 2443-3977 Volume 14 Number 2, 2016.

[16] Dhandhun W, Ratna W. D, Achmad, A.R. Adaptation of Coastal Communities in Demak Regency in Facing Climate Change and Coastal Region Disasters. Book Series on the Management of the Emerald Environment Equatorial. Master in Coastal and Watershed Management Planning (MPPDAS), Faculty of Geography, Gadjah Mada University. Kanisius Printing Yogyakarta, 2013.

[17] Weny H. Sihombing, Suntoyo, Kriyo S. Study of Sea Level Rise in the Coastal Region of Tuban Regency, East Java. Journal of Engineering,Vol. 1, (Sept, 2012) ISSN: 23019271, 2012.

[18] Thomas Triadi Putranto, and Kristi Indra Kusuma. Groundwater Problems in Urban Areas. Journal of Engineering - Vol. 30 No. 1 of 2009, ISSN 0852-1697, 2009.

[19] Tano, R.A., Aman, A., Toualy, E., Kouadio, Y.K., Francois-Xavier, B.B.D. and Addo, K.A. Development of an Integrated Coastal Vulnerability Index for the Ivorian Coast in West Africa. Journal of Environmental Protection, 9, 1171-1184, 2018.

[20] Diposaptono S, Budiman, and Firdaus A. Deal with Climate Change in Coastal Areas and Small Islands. PT. Main Means of Communication, Bogor. ISBN 978-979-129106-3, 2009.

[21] Marfai M. A, and King. Coastal Flood Management in Semarang. Environmental Geology Journal, DOI 10.1007 / s00254-007-1101-3 Volume 55 pages 1507-1518, 2008.

[22] Bengen, D G. Technical Guidelines for Introduction and Management of Mangrove Ecosystems. Bogor: Center for the Study of Coastal and Ocean Resources. Bogor: Institut Pertanian Bogor, 1999.

[23] Arief, A. Mangrove Forest, Functions and Benefits. Yogyakarta: Kanisius, 2003.

[24] Twigg, John. Characteristics of a Disaster-Resilient Community. University of London: Aon Benfield Hazard Research Centre, 2007.

[25] Arbriyakto D, and Kardyanto D. Identification of Measurement of Physical Loss in House Building and Social Losses in Residents of Coastal Areas of Semarang City. Proceeding Seminar on Losses in Buildings and Regions Due to Sea Level Rise in Coastal Cities in Indonesia. Semarang: Universitas Diponegoro, 2006.

[26] Nurnawaty. Experimental Study Of Soil Cement Barrier Model To Reduced Saltwater Intrusion At Coastal Aquifer. Hasanuddin University. 2017. 
[27] Weny H. Sihombing, Suntoyo, and Kriyo S. Study of Sea Level Rise in the Coastal Region of Tuban Regency, East Java. Engineering of Journal, Vol. 1, (Sept, 2012) ISSN: 2301-9271. 2012. 